\title{
Prostate Cancer Antigen 3
}

National Cancer Institute

\section{Source}

National Cancer Institute. Prostate Cancer Antigen 3. NCI Thesaurus. Code C92559.

Prostate cancer antigen $3(\sim 4 \mathrm{~kb})$ is encoded by the human PCA3 gene. This non-coding RNA may be involved in prostate carcinoma. 